\title{
The Study of Obtaining Composite Nickel Electroplatings with Detonation Nanodiamonds and Diamond Charge
}

\author{
V.Yu. Dolmatov ${ }^{1}$, G.K. Burkat ${ }^{2}$, I.V. Safronova ${ }^{2}$, A. Vehanen ${ }^{3}$, \\ V. Myllymäki ${ }^{3}$, V.A. Marchukov ${ }^{1}$, N.S. Almazova ${ }^{1}$, Yu.V. Litovka ${ }^{4}$, I.A. Dyakov ${ }^{4}$ \\ ${ }^{1}$ Special Design and Technological Bureau "Technologist”, 33-a, Sovetskiy pr., St. Petersburg, 192076, Russia; \\ ${ }^{2}$ St. Petersburg State Technological Institute (Technical University), 26, Moskovsky pr., St. Petersburg, 190013, Russia; \\ ${ }^{3}$ Carbodeon Ltd. Oy, 5, Pakkalankuja, Vantaa, 01510, Finland; \\ ${ }^{4}$ Tambov State Technical University, 106, Sovetskaya st., Tambov, 392000, Russia \\ * Corresponding author. Tel.: +7 81270023 10;+7 81224473 73. E-mail: diamondcentre@mail.ru
}

\begin{abstract}
The paper presents the results of studying the nickel electroplating process in the presence of nanodiamond additives. It shows that the use of detonation nanodiamonds (DND) and diamond explosive charge (DC) obtained by explosion of tetryl (N-methyl-2,4,6-trinitrophenylnitramine) can significantly improve the physicochemical properties of nickel platings: increase the microhardness up to $60 \%$ (up to $448 \mathrm{kgf} / \mathrm{mm}^{2}-4393 \mathrm{MPa}$ ), obtain a non-porous nickel plaiting and reduce wear up to 28 times. The most effective was the use of non-expensive nanodiamonds, but cheap diamond charge obtained by the explosion of tetrile.
\end{abstract}

Keywords

Nickel electroplating; detonation nanodiamonds; diamond charge; nickel; wear resistance; corrosion resistance.

(c) V.Yu. Dolmatov, G.K. Burkat, I.V. Safronova, A. Vehanen, V. Myllymäki, V.A. Marchukov, N.S. Almazova, Yu.V. Litovka, I.A. Dyakov, 2020

\section{Introduction}

Chromium and nickel electroplaitings are quite widespread in mechanical engineering. However, the widespread use of nickel plaiting is hindered by low wear and corrosion resistance.

The study [1] showed that to achieve high microhardness, wear and corrosion resistance, it is necessary to apply the plaiting from electrolytes containing additives of nanomaterials.

It is known that DND was used under the patent [2]. The disadvantages of this method include the high volume of labor costs for preparing the DND suspension in the electrolyte (up to 50 hours at a temperature of $55{ }^{\circ} \mathrm{C}$ ); the need to introduce a suspension of nanomaterials into the electrolyte in equal small portions; low stability of nanodiamonds in the electrolyte; low quality indicators of composite nickel plaiting.

The composite nickel plaiting with a microhardness of $292-374 \mathrm{kgf} / \mathrm{mm}^{2}(2864-3668 \mathrm{MPa})$ was obtained from an electrolyte [3] containing salts of nickel sulfates and DND with a concentration of 2 to $42 \mathrm{~g} / \mathrm{L}$ at a high current density of $15 \mathrm{~A} / \mathrm{dm}^{2}$. The disadvantages of this method include the high energy consumption, high consumption of nanodiamonds, as well as complex operations for the preparation of nanodiamonds (treatment of DND with acids, alkalis, and disintegrator) to the introduction into the electrolyte with a modest result.

In [4], when applying Ni-DND plaiting from the classical Watts electrolyte, the authors managed to increase the microhardness from 242 to $412 \mathrm{kgf} / \mathrm{mm}^{2}$ (from 2373 to $4040 \mathrm{MPa}$ ), while the concentration of DND-TAN was $2 \mathrm{~g} / \mathrm{L}$, and the current density was 1 or $2 \mathrm{~A} / \mathrm{dm}^{2}$. The wear of such a plaiting dropped by 2-4 times. DND was obtained by the explosion of an alloy of TNT with hexogen in a 50/50 ratio.

In [5], the effect of a diamond charge, an intermediate product of DND synthesis, also obtained by the explosion of an alloy of TNT with hexogen, on the nickel plaiting deposition process and its results was studied. The classical Watts electrolyte was also used. 
Even more significant results were obtained: at a DC content of $5 \mathrm{~g} / \mathrm{L}$ and a current density, the microhardness increased from 280 to $520 \mathrm{kgf} / \mathrm{mm}^{2}$ (from 2746 to $5100 \mathrm{MPa}$ ), the wear of the plaiting fell from $\sim 23 \%$ to $\sim 1 \%$, i.e. the wear resistance increased by $\sim 23$ times, and the porosity of the Ni-AL plaiting decreased from $\sim 17 \%$ to $2.5 \%$.

The aim of this work is to obtain low-porosity and wear-resistant nickel platings by adding detonation nanodiamonds and diamond charge obtained by the explosion of tetryl (N-methyl-2,4,6-trinitrophenylnitramine) to the electrolyte.

\section{Experimental part}

\section{Obtaining nanodiamonds and electrolysis mode}

A diamond charge was obtained by detonating charges from an individual explosive (tetril) in an Alfa-2M explosive chamber with a capacity of $2.14 \mathrm{~m}^{3}$. Detonation nanodiamonds (DND) were obtained from DC by purifying it with a mixture of $10 \%$ wt. $\mathrm{HNO}_{3}$ with $10 \%$ wt. $\mathrm{NH}_{4} \mathrm{NO}_{3}$ [6].

The object of the research was an electrolyte close in composition to Watts's electrolyte and contained:

- heptahydrate nickel sulfate - 205-215 g/l;

- sodium chloride - 11-16 g/1;

- boric acid - 21-26 g/1;

$-\mathrm{pH}-4.1-4.4$;

- electrolysis temperature, average $19^{\circ} \mathrm{C}$;

- current density $-0.6-2.1 \mathrm{~A} / \mathrm{dm}^{2}$.

The working electrode was a nickel-plated copper plate. The auxiliary electrodes were pure nickel plates. Polarization curves were recorded in potentiostatic mode. Each experiment was repeated 2 or 3 times.

\section{Determination of corrosion currents}

An IPC ProMF potentiostat was used to determine the corrosion currents. Corrosion curves were recorded in an aqueous $3 \% \mathrm{NaCl}$ solution in a potentiostatic mode $(1 \mathrm{mV} / \mathrm{s})$. Cathodic curves were obtained in the range of -1780 to $2110 \mathrm{mV}$ and anodic curves were obtained in the range of -1780 to $1710 \mathrm{mV}$.

\section{Procedure for determining corrosion resistance}

A KKI 1 salt spray chamber was used.

For conducting the tests, a sodium chloride solution with a concentration of $(50 \pm 5) \mathrm{g} / \mathrm{dm}^{3}$, $\mathrm{pH}$ 6.5-7.2 was used according to GOST 9.308-85.

While testing, the samples were placed in a KKI 1 chamber heated to a temperature of $(35 \pm 2){ }^{\circ} \mathrm{C}$ and exposed to salt fog. During the tests, the solution was sprayed continuously. The average filling rate of the solution in each collector for $24 \mathrm{~h}$ was $1-2 \mathrm{~cm}^{3} / \mathrm{h}$. At the end of the tests, the samples were removed from the chamber. The assessment of corrosion damage was carried out in accordance with GOST 9.311-87 and GOST 9.908-85.

\section{Methods for determining microhardness}

The microhardness tester PMT-3 was used.

The microhardness measurement was based on the method of static indentation of a diamond pyramid under a low load (20 g) into the plaiting under study. The measurements were carried out in accordance with GOST 9.450-76. The resulting rhombic imprint (on the thin section of the plaiting) was observed under a microscope. The average value of the imprint diagonal was taken from 9 to 13 measurements on each sample.

The microhardness value (MPa) was calculated by the formula:

$$
H_{\mu}=\frac{1854 P \cdot 9.8}{(0.3 d)^{2}},
$$

where $P$ is the load, g; $d$ is average diagonal of the print, $\mu \mathrm{m}$.

In order to measure the microhardness, plaitings with a thickness of $15 \mu \mathrm{m}$ were applied to the steel base, which exceeds the minimum thickness of galvanic deposits in the case when the base is softer than the plaiting. The average microhardness value was obtained from five experiments. The measurement error was $\pm 6 \%$.

\section{Procedure for determining porosity}

The potentiostat IPC ProMF was used.

The porosity in this work was measured by the method of anodic polarization curves in a $0.1 \mathrm{~N}$ solution of potassium thiocyanate on a steel sample with a nickel plaiting. On the recorded polarization curves, we chose the potential at which the steel dissolves and the nickel plaiting was in a passive state. At this potential, current-time curves were recorded. The pore area in the plaiting was calculated using the formula:

$$
S_{\text {pore }}=i_{\mathrm{st}}+\mathrm{Ni} / i_{\mathrm{st}},
$$

where $i_{\mathrm{st}}+\mathrm{Ni}$ is constant anode current established at the selected potential on steel with nickel plating, $\mathrm{mA} / \mathrm{cm}^{2} ; i_{\mathrm{st}}$ is constant anode current established at the selected potential on steel, $\mathrm{mA} / \mathrm{cm}^{2}$.

The thickness of the investigated plaiting was $5 \mu \mathrm{m}$. The average porosity value for each type of plaiting was obtained from 3 to 5 experiments. The measurement error was $\pm 5 \%$. 


\section{Discussion of the results}

\section{Micrographs of nickel plaiting}

The addition of DND-TAN (T) and DC (T) to the nickel-plating electrolyte led to a change in the plaiting structure as compared to the structure of similar plaiting that did not contain nanodiamond additives.

Fig. 1 demonstrates that the surface of the nickel plaiting without nanodiamond additives is inhomogeneous and has a clearly pronounced layered structure. The microcracks are observed which increases the porosity of the plaiting. The nickel grain size is $\sim 240 \mathrm{~nm}$.

Adding only $1 \mathrm{~g} / \mathrm{l}$ of DND-TAN (T) to the electrolyte causes a change in the plaiting structure (Fig. 2). The nickel plaiting becomes more uniform, but its layered structure is retained, microcracks are less pronounced, and the formation of aggregated DND-TAN (T) particles is visible on the surface. The nickel grain size dropped from 240 to $215 \mathrm{~nm}$. It was previously shown that DND, especially DND-TAN (T), have surface-active properties and affect the structure of the plaiting.

An increase in the concentration of DND-TAN (T) in the electrolyte (Fig. 3) significantly affects the structure of the plaiting - the nickel deposit becomes much more uniform and the number of cracks decreases. The nickel grain size naturally drops to $145 \mathrm{~nm}$, as a larger number of nanodiamond particles gives rise to a larger number of nickel crystallization centers.

As can be seen from Fig. 4 DC (T), has a more significant effect on the structure of the nickel plaiting than DND-TAN (T) of the same concentration in the electrolyte. The leveling of the nickel deposit surface and a significant decrease in the number of cracks are observed. Aggregates of various sizes are visible on the deposit surface. Faceted particles are noticeable at higher magnification. In this case, not only nanodiamond particles but also graphite-like carbon particles are introduced into the nickel plaiting. Nickel grains are $\sim 185 \mathrm{~nm}$ in size.

With an increase in the concentration of DC $(\mathrm{T})$ in the electrolyte to $5.0 \mathrm{~g} / 1$ (Fig. 5), the nickel deposit surface is further leveled and fracturing decreases and, accordingly, the porosity decreases. Like DND-TAN (T), DC (T) has pronounced surfactant properties that affect the surface tension of the electrolyte. On the surface of the nickel deposit, both rather large and small aggregates are clearly visible, which shows a significant difference in the particle size in the DC (T). The average nickel grain size in the plaiting is $\sim 170 \mathrm{~nm}$.
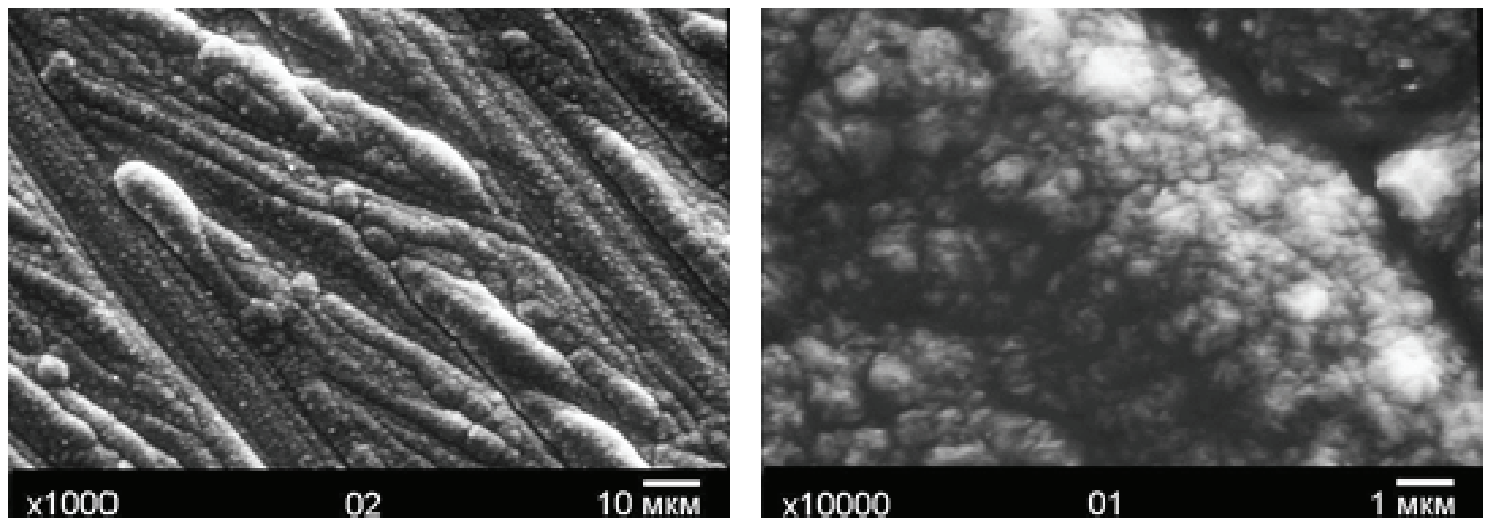

Fig. 1. Micrograph of nickel plaiting (without nanodiamond additives)
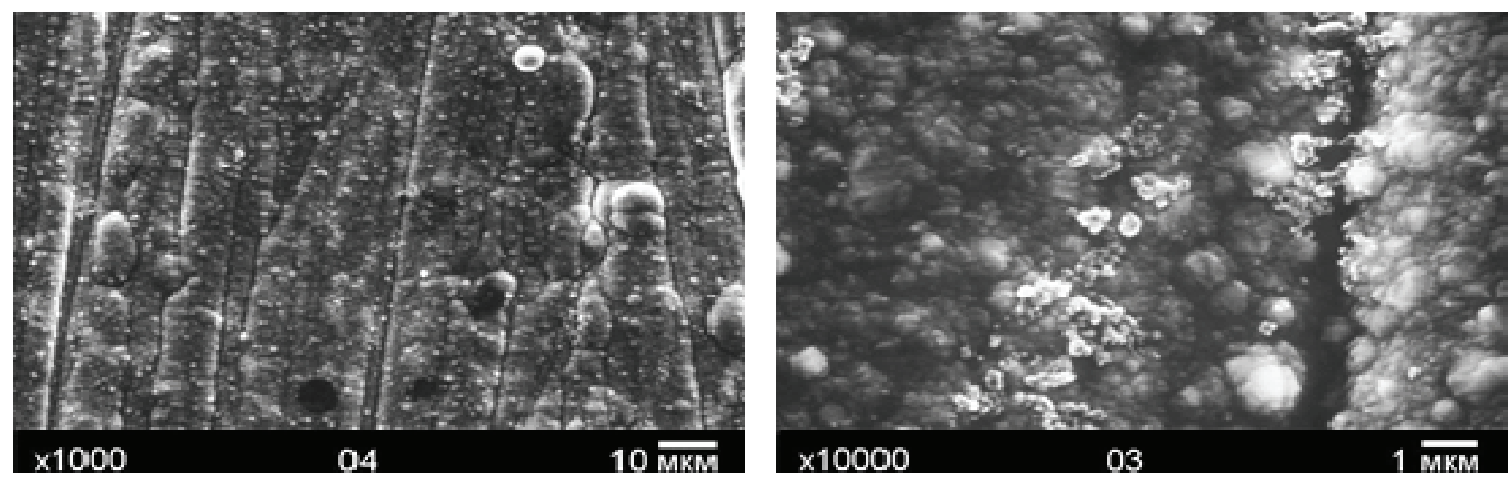

Fig. 2. Micrograph of the nickel plaiting (DND-TAN (T) $1.0 \mathrm{~g} / \mathrm{l}$ ) 

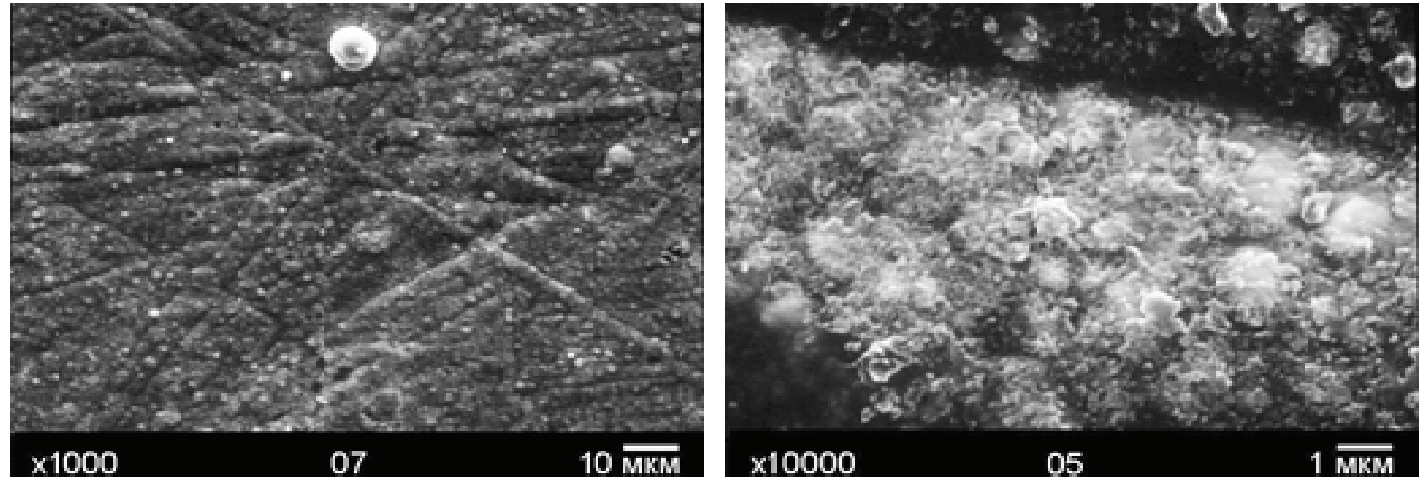

Fig. 3. Micrograph of the nickel plaiting (DND-TAN (T) $5.0 \mathrm{~g} / \mathrm{l}$ )
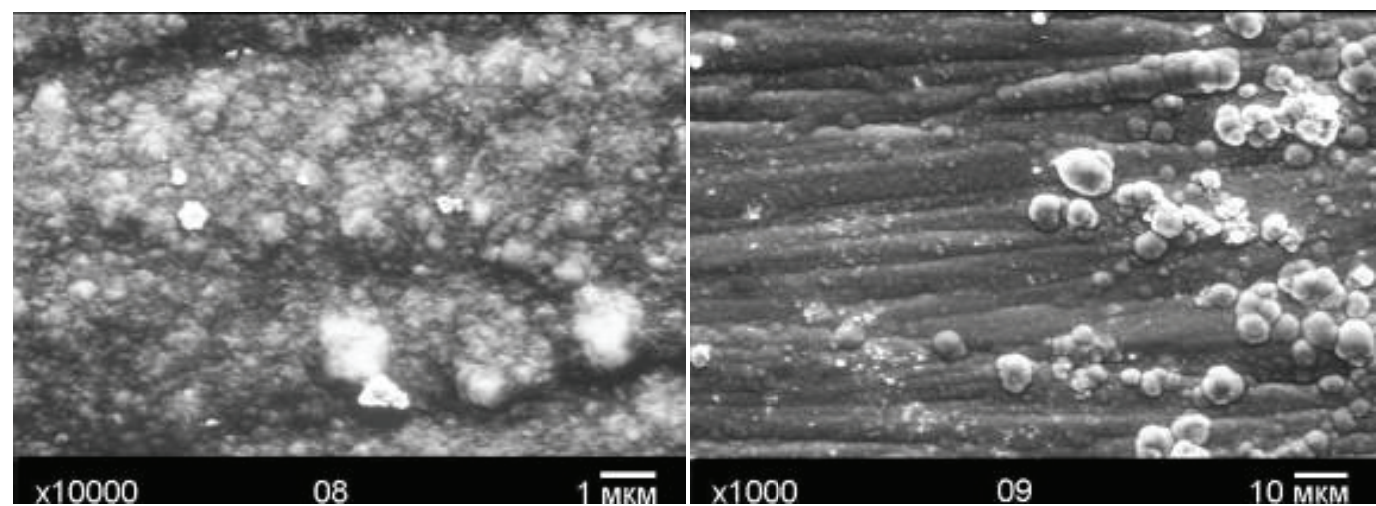

Fig. 4. Micrograph of the nickel plaiting (DC (T) $1.0 \mathrm{~g} / \mathrm{l})$
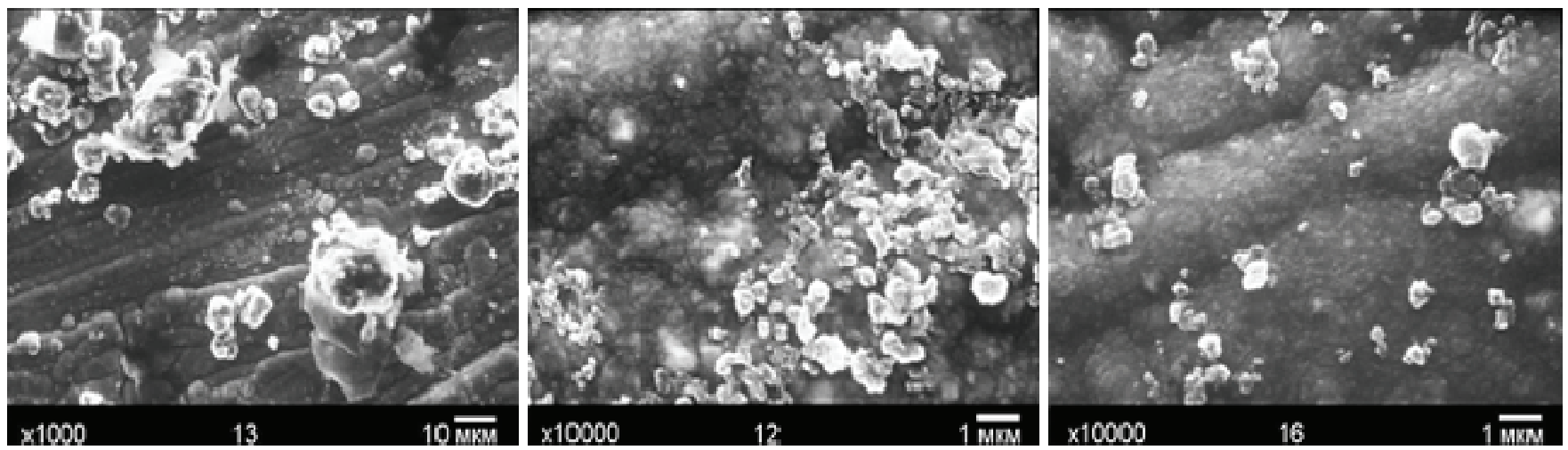

Fig. 5. Micrograph of the nickel plaiting (DC (T) $5.0 \mathrm{~g} / \mathrm{l}$ )

\section{The dissipative power of the electrolyte}

To assess the scattering ability of the nickelplating electrolyte (uniformity of plaiting) with DNDTAN (T) and DC (T), the electrical conductivity of electrolytes was studied at first (Table 1).

The addition of low-conductivity tetrile DNDTAN (T) leads to the insignificant increase in the electrical conductivity of the electrolyte, while the use of tetryl DC (T) significantly increases the electrical conductivity. This is due to the fact that the surface of tetryle DC (T) contains a noticeable amount of unsaturated carbon bonds, including carbonyl groups, as well as amine and amide groups. Due to this, as well as the graphite component of the DC (T), electronic transfer occurs between the particles of the DC (T) and the redox particles in the electrolyte or on the electrode.

The quality and properties of plaitings are largely determined by the uniformity of metal distribution over the layer thickness, i.e. scattering power, and the scattering power depends on the polarizability and electrical conductivity, which characterize the criterion of electrochemical similarity $G$. It is often used to determine the current dissipation of electrolytes. 
Influence of temperature on the electrical conductivity of electrolytes $\chi,\left(\mathrm{cm} / \mathrm{cm}^{2}\right) \cdot 10^{2}$

\begin{tabular}{ccccc}
\hline & \multicolumn{4}{c}{ Temperature of electrolyte, ${ }^{\circ} \mathrm{C}$} \\
Nanodiamond additive, g/l & $50 \pm 1$ & $40 \pm 1$ & $30 \pm 1$ & $20 \pm 1$ \\
\hline- & 8.13 & 7.21 & 6.06 & 4.82 \\
DND-TAN (T), 1.0 & 8.23 & 7.50 & 6.20 & 5.07 \\
DND-TAN (T), 2.0 & 8.62 & 7.85 & 6.61 & 5.19 \\
DND-TAN (T), 5.0 & 8.58 & 7.93 & 6.66 & 5.62 \\
DC (T), 1.0 & 11.47 & 9.97 & 8.88 & 7.50 \\
DC (T), 2.0 & 11.39 & 10.03 & 8.92 & 7.40 \\
DC (T), 5.0 & 11.88 & 10.33 & 9.09 & 7.80 \\
\hline
\end{tabular}

The polarizability $\Delta E / \Delta i_{k}$ was determined from the corresponding polarization curves, and the electrical conductivity of the electrolyte $\chi$ was measured using a conductometer. The same electrolyte was chosen as the basic composition of the electrolyte, while the concentration of additives in the electrolyte was insignificant, therefore, most likely, it was the polarizability value that would have the greatest effect on the value of $G$. Initially, the electrical conductivity of the electrolyte with DND-TAN (T) and DC (T) was determined.

It is known that electrolytes for nickel plating have poor scattering ability, and the electrical conductivity of the electrolyte increases G. Table 2 shows that the presence of DC $(\mathrm{T})$ increases the electrical conductivity by $\sim 1.5$ times, which is associated with the presence of graphite-like components in the DC (T). Therefore, DC (T) can have a significant effect not only on the $G$-factor, but also on the properties of the applied plaiting.
Table 3 provides an estimate of the $\mathrm{G}$-factor for nickel electrolytes. The addition of DNA-TAN (T) at a concentration of $5 \mathrm{~g} / 1$ increases the G-factor by $\sim 1.4$ times. However, the addition of DC (T) at only $2 \mathrm{~g} / \mathrm{l}$ increases the G-factor by $\sim 1.96$ times.

\section{Nickel current output}

Nickel current efficiency is an important characteristic of nickel plating electrolyte (Table 4). Earlier it was shown that the use of DC (T) increases the overpotential of hydrogen evolution and thereby increases the nickel current efficiency as the concentration of DC (T) increases up to $97-99 \%$. However, the use of DND-TAN (T) does not allow increasing the current efficiency of nickel: it remains within 91-93\%, which agrees with the hydrogen curves for electrolytes both without this additive and with it.

Thus, when using DC (T), we can raise the nickel current output to $97-99 \%$ (maximum value).

Table 2

Influence of DND-TAN (T) and DC (T) concentration on the electrolyte conductivity $\chi(\mathrm{cm} / \mathrm{cm}) \cdot 10^{2}$ from concentration

Nanodiamond additive

The amount of nanodiamond additives, $\mathrm{g} / \mathrm{l}$

\begin{tabular}{ccccc} 
& - & 1.1 & 2.1 & 5.2 \\
\hline DND-TAN (T) & 4.882 & 5.056 & 5.181 & 5.618 \\
DC (T) & 4.882 & 7.304 & 7.497 & 7.798 \\
\hline
\end{tabular}


Criterion of electrochemical similarity for electrolyte with nanodiamond additives, $\Delta i_{k}=0,01 \mathrm{~A} / \mathrm{cm}^{2}$

Table 3

\begin{tabular}{ccccc}
\hline $\begin{array}{c}\text { Additive content } \\
\text { in nickel electrolyte, g/l }\end{array}$ & $\Delta E, \mathrm{~B}$ & $\begin{array}{c}\text { Electrode } \\
\text { polarizability } \\
\Delta E / \Delta i_{k}, \mathrm{Ohm} \cdot \mathrm{cm}^{2}\end{array}$ & $\begin{array}{c}\text { Electrical } \\
\text { conductivity } \\
\text { of the solution } \chi, \\
\left(\mathrm{cm}^{2} \mathrm{~cm}^{2}\right) \cdot 10^{2}\end{array}$ & $\begin{array}{c}\text { Coefficient } \\
\text { of electrochemical similarity } \\
G=\chi \cdot \Delta E / \Delta i_{k}, \mathrm{~cm}\end{array}$ \\
\hline- & 0.051 & 4.882 & & 24,0 \\
DND-TAN (T) - 1.0 & 0.051 & 5.056 & 5.1 & 24.2 \\
DND-TAN (T) -2.0 & 0.049 & 5.181 & 4.9 & 25.2 \\
DND-TAN (T) - 5.0 & 0.059 & 5.618 & 5.9 & 33.4 \\
DC (T) - 1.0 & 0.056 & 7.497 & 5.6 & 42.1 \\
DC (T) - 2.0 & 0.066 & 7.304 & 6.6 & 47.3 \\
DC (T) -5.0 & 0.062 & 7.798 & 6.2 & 48.2 \\
\hline
\end{tabular}

Table 4

Nickel output (with DC and DND) by current

\begin{tabular}{ccccc}
\hline DC & \multicolumn{4}{c}{$i_{k}, \mathrm{~A} / \mathrm{dm}^{2}$} \\
$\begin{array}{c}\text { and DND-TAN (T) } \\
\text { content, g/ }\end{array}$ & 1.1 & 1.3 & 1.6 & 1.8 \\
\hline \multicolumn{5}{c}{ DC } \\
- & 93 & 94 & 92 & 92 \\
1.1 & 95 & 96 & 96 & 96 \\
1.6 & 93 & 92 & 95 & 95 \\
2.1 & 99 & 94 & 95 & 93 \\
5.2 & 97 & 100 & 95 & 91 \\
\multicolumn{5}{c}{ DND-TAN } \\
1.1 & 93 & 94 & 92 & 92 \\
2.1 & 92 & 91 & 93 & 91 \\
5.2 & 93 & 91 & 91 & 92 \\
& 91 & 92 & 92 & 91 \\
\hline
\end{tabular}

\section{Microhardness of nickel-diamond plaiting}

During electrochemical deposition, DND-TAN (T) and $\mathrm{DC}(\mathrm{T})$ particles are embedded in the crystal structure of the plaiting forming dislocations in the deposit and changing the strength properties of nickel. In addition, DND-TAN (T) and DC (T) particles embedded in the plaiting are microbarriers when microcracks appear which also strengthens the nickel plaiting. In the previous studies it was shown that DND and DC have surface-active properties which contributes to the decrease in the grain of the nickel plaiting.

Table 5 shows that the use of DC (T) and DNDTAN (T) leads to the significant increase in the microhardness of the nickel plaiting.
Table 5

Microhardness of plaiting, MPa

\begin{tabular}{lccc}
\hline \multirow{2}{*}{ Additive } & $\begin{array}{c}\text { Content } \\
\text { of electrolyte } \\
\text { additives, g/ }\end{array}$ & \multicolumn{2}{c}{$i_{k}, \mathrm{~A} / \mathrm{dm}^{2}$} \\
\hline- & - & 2736 & 2324 \\
DC (T) & 1.1 & 4393 & 3119 \\
& 2.1 & 3472 & 3481 \\
DND-TAN (T) & 5.2 & 3893 & 3226 \\
& 1.1 & 3746 & 3344 \\
& 2.1 & 3746 & 3472 \\
& 5.2 & 3893 & 3472 \\
\hline
\end{tabular}

The introduction of diamond additives increases the microhardness of the nickel plaiting in comparison with the nickel plaiting without nanodiamond additives. The difference between the effect on the microhardness of DND-TAN (T) and DC (T) is small: in the first case, the increase in microhardness is $40-48 \%$, and in the case of using a tetrile mixture it is $41-43 \%$. However, for nickel plating, the microhardness is only a preliminary approximate value for assessing the physicochemical properties. The wear resistance and corrosion resistance of the plaiting are of paramount importance.

\section{Wear resistance of the nickel plating}

Tribochemical processes are very complex and in this work we consider only the resultant abrasion of samples with pure nickel and nickel-diamond plating. The wear of the plating during abrasion was determined by weighing, and the results are shown in Figs. 1 and 2. 


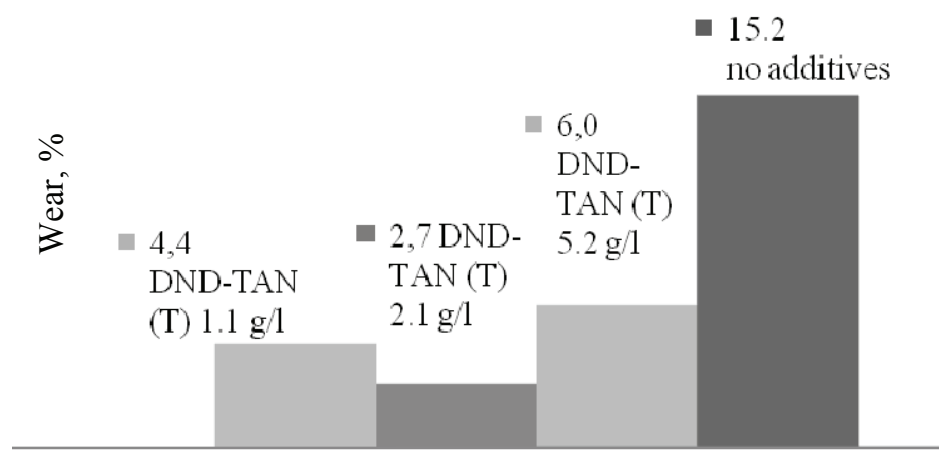

Fig. 6. Wear diagram of nickel electrolyte plating with DND-TAN (T), $i_{k}$ additive $1,1 \mathrm{~A} / \mathrm{dm}^{2}$

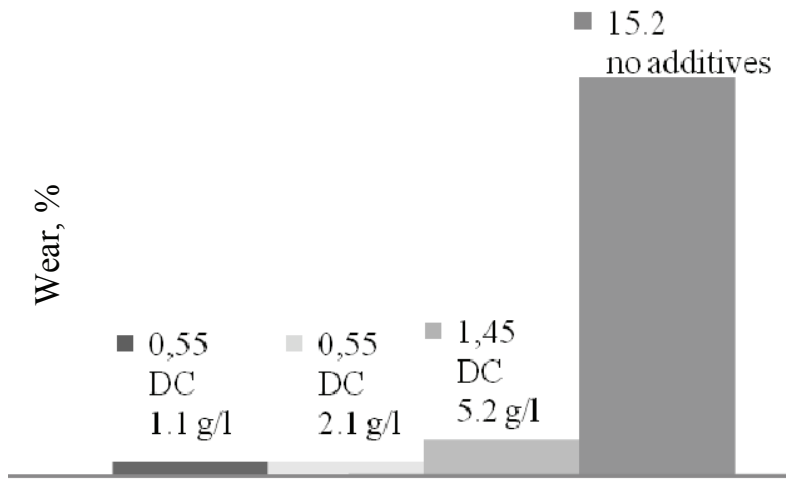

Fig. 7. Wear diagram of the deposit samples of a nickel electrolyte with the DC addition, current density $1 \mathrm{~A} / \mathrm{dm}^{2}$

Table 6 (62\% wt.) of diamond nanocrystals, and DND-TAN (T) consists almost entirely of DND, the latter are embedded in the nickel plating and create a composition that is sufficiently resistant to abrasion. At the same time, DC (T) contains $38 \%$ wt. graphitelike structures. Thus, getting into the plating, nanographite significantly reduces the coefficient of friction and the combined action of DND and nanographite reduces wear by $\sim 28$ times, but the use of individual DND-TAN (T) leads to a decrease in wear only by $\sim 6$ times.

\section{Porosity of the nickel-diamond plating}

Obtaining a non-porous nickel plating is critical. As a rule, electrochemical nickel plating is almost always porous. At the same time it is a cathode plating and can protect the matrix from possible corrosion only in the absence of pores. Studies of the porosity of the platings were carried out by obtaining anodic polarization curves (current-time).

\section{Porosity of Ni-DC (T) platings}

The current-time curves for a plating obtained from a nickel electrolyte with different concentrations of DC (T) are located in the region of very low current loads, and in the presence of DC (T), the curves are located significantly lower than the curve obtained from an electrolyte without additives, which indicates a decrease in porosity.

Table 6 shows the calculation of the pore area for the deposition of nickel platings. Table 6 shows that the minimum porosity is available for the nickel plating at a current density of $1.1 \mathrm{~A} / \mathrm{dm}^{2}$ and $\mathrm{DC}(\mathrm{T})$ concentration in the electrolyte of $1.1-1.6 \mathrm{~g} / 1$. It is 515 times less than that of the plating without additives. At the same time, nickel platings obtained at DC (T) concentration in the electrolyte of $2.1 \mathrm{~g} / 1$ and a current density of $1.1-1.6 \mathrm{~A} / \mathrm{dm}^{2}$ have quite acceptable porosity.

\section{Pore area of nickel platings (electrolyte with DC (T))}

\begin{tabular}{ccccc}
\hline \multicolumn{5}{c}{ Plating pore area with DC, \% } \\
\hline $\begin{array}{c}\text { Content } \\
\text { of DC (T) }\end{array}$ & \multicolumn{5}{c}{ Plating thickness $-3 \mu \mathrm{m}$} \\
in electrolyte, g/1 & 1.1 & 1.3 & 1.6 & 1.8 \\
\hline Pure Ni & 20.7 & 23.2 & 32.6 & 47.1 \\
1.1 & 0.16 & 4.6 & 2.3 & 3.7 \\
1.6 & 0.04 & 1.6 & 4.0 & 8.5 \\
2.1 & 1.2 & 1.5 & 1.6 & 9.7 \\
5.2 & 5.7 & 9.3 & 6.3 & 1.2 \\
\hline
\end{tabular}

\section{Porosity of Ni-DND-TAN (T) platings}

The data obtained from the current-time curves for a nickel electrolyte plating with different concentrations of DND-TNA (T) are shown in Table 7.

Table 7

Pore area of nickel platings with DND-TAN (T)

\begin{tabular}{ccccc}
\hline $\begin{array}{c}\text { Content } \\
\text { of DND-TAN (T) } \\
\text { in electrolyte, g/1 }\end{array}$ & \multicolumn{4}{c}{ Pore area $i_{k}, \mathrm{~A} / \mathrm{dm}^{2}$} \\
\hline- & 1.1 & 1.3 & 1.6 & 1.8 \\
\hline 1.1 & 20.7 & 23.2 & 32.6 & 47.1 \\
2.1 & 16.0 & 16.0 & 23.1 & 20.3 \\
5.2 & 26.9 & 19.4 & 18.2 & 7.6 \\
\hline
\end{tabular}


Physicochemical properties of the nickel plating including DND-TAN (T) and DC (T)

\begin{tabular}{|c|c|c|c|}
\hline \multirow[b]{2}{*}{ Properties } & \multicolumn{3}{|c|}{ Current density $1,1 \mathrm{~A} / \mathrm{dm}^{2}$} \\
\hline & $\begin{array}{c}\text { Electrolyte } \\
\text { with out additives }\end{array}$ & $\begin{array}{c}\text { Electrolyte } \\
\text { with DND-TAN (T) } 1,1 \mathrm{~g} / 1\end{array}$ & $\begin{array}{l}\text { Electrolyte } \\
\text { with DC (T) } 1,1 \mathrm{~g} / 1\end{array}$ \\
\hline $\begin{array}{l}\text { Micrograph } \\
\text { of the deposit surface }\end{array}$ & & & 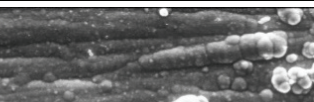 \\
\hline Microsection structur & & & \\
\hline Microhardness, MPa & 2628 & 3746 & 3217 \\
\hline Pore area, $\%$ & 20.7 & 16.0 & 0 \\
\hline Wear, \% & 15.2 & 4.5 & 0.55 \\
\hline
\end{tabular}

Table 7 shows that the lowest porosity is achieved when using DND-TAN (T) with a concentration of $2.1-5.2 \mathrm{~g} / \mathrm{l}$ in nickel electrolyte at a current density of $1.8 \mathrm{~A} / \mathrm{dm}^{2}$ ( $\sim 6$ times less than that of the nickel plating without additives). However, the pore-free nickel plating obtained with the DC $(\mathrm{T})$ introduced into the electrolyte is incomparable with the quality of the same plating when using DND-TAN (T), where the significant porosity is observed.

The obtained data on porosity are consistent with the results of determining the corrosion resistance in the salt spray chamber. The final data, including micrographs of the surface of thin sections of nickel platings, are given in Table 8 .

Comparison of the data in Table 8 implies the absolute advantage of using DC (T) in the nickel codeposition from the classic Watts electrolyte - the microhardness is entrained by $60 \%$ (compared to nickel plating without additives); the pore area is reduced from $20.7 \%$ (very high porosity) to practically zero, and the wear is reduced by 27.6 times.

\section{Conclusion}

1. Additives DND-TAN (T) and DC (T) have a strong effect on the microstructure of the nickel deposit during its electrochemical deposition, thickening the deposit and reducing the nickel grain size.
2. The microhardness of the plating increases up to $60 \%$ when using nanodiamond additives.

3. The wear resistance of the nickel plating when using DND-TAN (T) and DC (T) increases up to 28 times. The use of DND-TAN (T) turned out to be significantly less effective than the use of DC (T).

4. The use of $\mathrm{DC}(\mathrm{T})$ makes it possible to obtain practically pore-free nickel plating, while DND-TAN (T) allows to reduce the porosity by only 6 times at best.

\section{References}

1. Sajfullin R.S. Neorganicheskie Kompozitsionnye Materialy [Inorganic composite materials]. Moscow: Khimiya, 1983, 304 p. (Rus)

2. Nikitin E.V., Polyakov L.A., Kalugin N.A. Pokrytiya $s$ Vklyuchennymi $v$ nikh Materialami, naprimer, Chasticami, Spiral'nymi Pruzhinami, Provolokoj, Poluchaemye Elektroliticheskim Sposobom ili Sposobom Elektroforeza [Platings with materials included in them, for example, particles, spiral springs, wire, obtained by an electrolytic or electrophoresis method]. Patent RF 2156838 (publ. Bulletin No. 27, June 27, 2001). (Rus)

3. Larionova I.S., Belyaev V.N., Il'inykh K.F., Frolov A.V., Bychin N.V., Mitrofanov V.M. Sposob 
Polucheniya Kompozitsionnykh Pokrytij [Method of obtaining composite platings]. Patent RF 2357017 (publ. Bulletin No. 15, May 27, 2009). (Rus)

4. Burkat G.K., Gornickij I.V., Dolmatov V.Yu. Elektroosazhdenie Nikelya $v \quad$ Prisutstvii Nanouglerodnykh Dobavok [Electrodeposition of nickel in the presence of nanocarbon additives]. Izvestiya Sankt-Peterburgskogo gosudarstvennogo tekhnologicheskogo instituta. St. Petersburg, 2011, 11 (37), 97-99. (Rus)

5. Burkat G.K., Gornickij I.V. Vliyanie Almaznoj Shihty na Fiziko-khimicheskie Svojstva Nikelevykh Pokrytij [Influence of diamond charge on the physicochemical properties of nickel platings]. Izvestiya S-Peterburgskogo gosudarstvennogo tekhnologicheskogo institute, 2012, 16 (42), 23-25. (Rus)

6. Marchukov V.A., Kolodyazhnyj A.L., Makarov I.A., Korolyov K.M., Sushchev V.G. Sposob Ochistki Detonacionnyh Nanodispersnykh Almazov [Method for cleaning detonation nanodispersed diamonds]. Patent RF 2599665 (publ. Bulletin No. 28, October 10, 2016). (Rus)

7. Dolmatov V.Yu., Marchukov V.A., Sushchev V.G., Veretennikova M.V. Sposob Polucheniya Stabil'noj Suspenzii Detonacionnykh Nanoalmazov [Method of obtaining a stable suspension of detonation nanodiamonds]. Patent RF 2384524 (publ. Bulletin No. 8, March 20, 2010). (Rus)
Limited Liability Company "New materials and technologies for civil purposes" is a Russian innovative company created on the basis of the Federal State Budgetary Educational Institution of Higher Education "Tambov State Technical University", specializing in scientific and technical developments and engineering for the oil and gas, petrochemical and food industries.

It has its own research and production base. The employees are a team of professionals and qualified specialists who implement high-tech projects of any complexity.

The company uses the latest technologies and modern trends to improve the efficiency and profitability of production.

The company offers:

- Experimental design and technological work;

- Technological audit and optimization of production processes;

- Development of pilot installations;

- Development of technologies for obtaining new materials;

- Testing, research and certification of materials and products;

- Pilot industrial tests;

- Commissioning of engineering systems;

- Marketing, patent research and development of feasibility studies for the implementation of engineering projects.

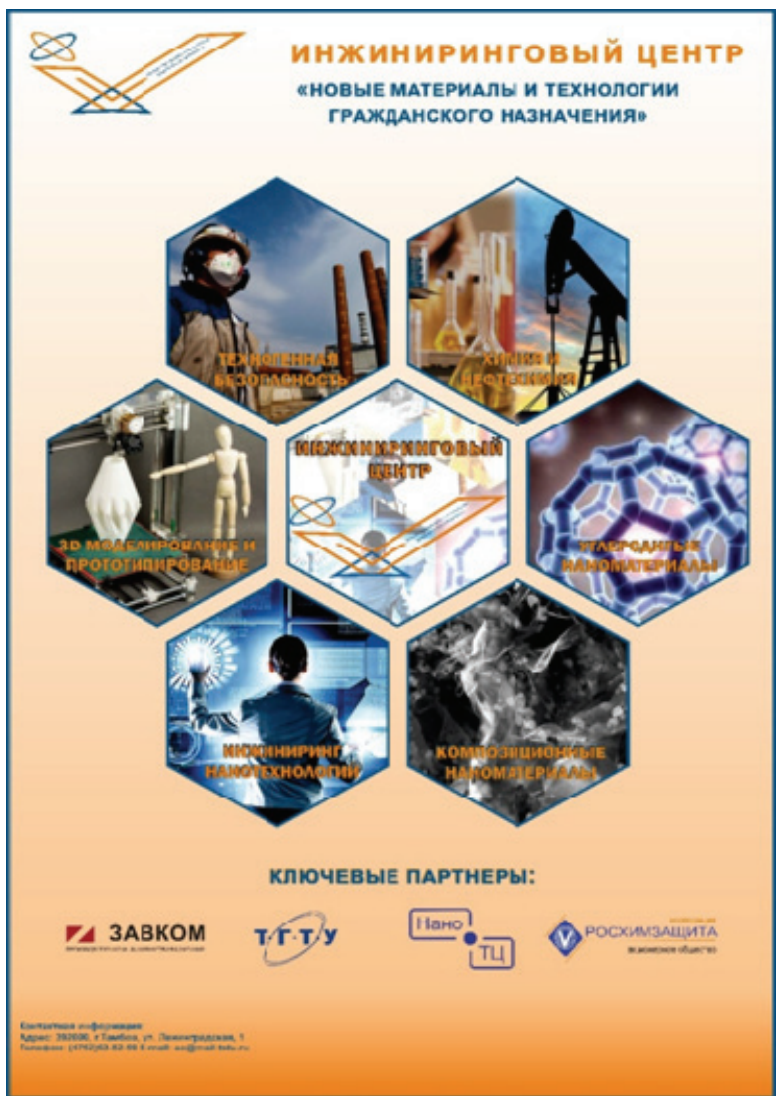

